\title{
Research priorities for the development and implementation of serological tools for malaria surveillance
}

\author{
Salenna R. Elliott ${ }^{1}$, Freya J.I. Fowkes ${ }^{1-3}$, Jack S. Richards ${ }^{1,3,4}$, Linda Reiling ${ }^{1}$, \\ Damien R. Drew ${ }^{1}$ and James G. Beeson ${ }^{1,3,4 *}$
}

Addresses: ${ }^{1}$ Burnet Institute, 85 Commercial Road, Melbourne, Victoria 3004, Australia; ${ }^{2}$ School of Epidemiology and Preventive Medicine, Monash University, 99 Commercial Road, Victoria 3004, Australia; ${ }^{3}$ School of Population Health and Department of Medicine (RMH), University of Melbourne, Victoria 3010, Australia; ${ }^{4}$ Department of Microbiology, Monash University, Victoria 3800, Australia

* Corresponding author: James G. Beeson (beeson@burnet.edu.au)

FI000Prime Reports 2014, 6:100 (doi:10.12703/P6-100)

All F1000Prime Reports articles are distributed under the terms of the Creative Commons Attribution-Non Commercial License (http:// creativecommons.org/licenses/by-nc/3.0/legalcode), which permits non-commercial use, distribution, and reproduction in any medium, provided the original work is properly cited.

The electronic version of this article is the complete one and can be found at: http://fl000.com/prime/reports/b/6/100

\begin{abstract}
Surveillance is a key component of control and elimination programs. Malaria surveillance has been typically reliant on case reporting by health services, entomological estimates and parasitemia (Plasmodium species) point prevalence. However, these techniques become less sensitive and relatively costly as transmission declines. There is great potential for the development and application of serological biomarkers of malaria exposure as sero-surveillance tools to strengthen malaria control and elimination. Antibodies to malaria antigens are sensitive biomarkers of population-level malaria exposure and can be used to identify hotspots of malaria transmission, estimate transmission levels, monitor changes over time or the impact of interventions on transmission, confirm malaria elimination, and monitor re-emergence of malaria. Sero-surveillance tools could be used in reference laboratories or developed as simple point-of-care tests for community-based surveillance, and different applications and target populations dictate the technical performance required from assays that are determined by properties of antigens and antibody responses. To advance the development of sero-surveillance tools for malaria elimination, major gaps in our knowledge need to be addressed through further research. These include greater knowledge of potential antigens, the sensitivity and specificity of antibody responses, and the longevity of these responses and defining antigens and antibodies that differentiate between exposure to Plasmodium falciparum and P. vivax. Additionally, a better understanding of the influence of host factors, such as age, genetics, and comorbidities on antibody responses in different populations is needed.
\end{abstract}

\section{Introduction}

In recent years, there has been a decline in malaria transmission in many regions, leading to optimism that malaria elimination might be achieved in numerous countries [1-6]. Declining transmission has been attributed in part to the upscaling of control efforts, such as rapid diagnosis and effective treatment, insecticide-treated bed nets, and vector control strategies. As transmission declines, surveillance becomes increasingly important $[1,7,8]$. Monitoring changes in malaria transmission intensity and disease prevalence through surveillance allows government and non-government agencies to plan and evaluate health services and control programs. Once transmission declines, surveillance helps to identify populations experiencing ongoing transmission for targeted interventions. Surveillance is particularly important in a pre-elimination context to identify asymptomatic carriers who might still transmit infection. Once elimination has been achieved, surveillance must continue in order to confirm a country or region's elimination status and to ensure that outbreaks resulting from re-introduced infection are quickly identified and controlled. 
Conventionally, malaria surveillance has been based on clinical case reporting by health services, entomological estimates (the entomological inoculation rate [EIR] is an estimate of the number of infectious bites per person per unit time), and parasitemia (Plasmodium species) point prevalence. However, these techniques become less sensitive and relatively expensive as transmission declines $[9,10]$. Sero-surveillance is the use of Plasmodium species-specific antibodies as biomarkers for monitoring exposure, transmission, and immunity and has significant potential to enhance the effectiveness of malaria control and elimination programs. Antibodies are a more sensitive marker of population-level malaria exposure in low-transmission settings and reflect exposure over a period of time, which is useful in areas with highly seasonal transmission $[8,10]$. Although this approach was used historically as part of malaria control programs [10], its use declined in part because of the lack of standardized antigens and methodology [10]. Recently, with the advent of recombinant proteins and improved technology for high-throughput screening, there is renewed interest in sero-surveillance for malaria.

\section{Potential applications of sero-surveillance in malaria control programs}

Several studies have explored the measurement of serum antibodies to recombinant malaria proteins by enzymelinked immunosorbent assay (ELISA), as a measure of malaria exposure, and a number of potential applications for sero-surveillance have been identified (Table 1). Seroprevalence provides a general indication of the level of endemicity, with seroprevalence peaking at an earlier age in regions with high transmission intensity [10]. Modeling of age-specific seroprevalence data may be used to estimate seroconversion rates (that is, the rate at which seronegative individuals became seropositive) [7,11-13] which have shown a strong association with measures of transmission intensity, such as malaria incidence, altitude, and EIR $[7,11,14]$.

Serology appears to be highly suitable for identifying trends in malaria transmission over time [11], and age-specific

Table I. Potential applications of sero-surveillance as part of malaria control programs

\begin{tabular}{l}
\hline Application \\
\hline Estimate level of malaria transmission in populations. \\
Monitor trends in transmission over extended periods of time (over years). \\
Evaluate the impact of malaria control interventions. \\
Identify individuals and populations with recent exposure (within several \\
months). \\
Identify focal areas ("hotspots") or populations ("hot-pops") with ongoing \\
transmission. \\
Confirm malaria elimination and monitor for re-emergence of malaria. \\
Screen for asymptomatic carriers. \\
Identify populations at high risk. \\
\hline
\end{tabular}

antibody prevalence rates can be used to estimate the time at which major changes in transmission occurred $[10,15,16]$. In hyperendemic settings where seroprevalence is high, a variation in antibody magnitude may be a more sensitive marker of changes in transmission $[10,14]$. Serosurveillance provides a more sensitive tool than screening for parasitemia by microscopy of blood smears or rapid diagnostic tests for evaluating the impact of control interventions on transmission, particularly when transmission intensity is already low [14].

Sero-surveillance has also proven to be a valuable method for identifying transmission hotspots and population groups at higher risk of infection [12-14,16-18]. As transmission decreases, it becomes more heterogeneous, concentrated in defined geographic areas ("hotspots") and high-risk subpopulations ("hot-pops") [18,19]. In parallel, the proportion of individuals with sub-microscopic infection increases, contributing substantially to ongoing transmission $[9,20]$ and posing a challenge to those seeking to identify and eliminate persisting malaria reservoirs. Although polymerase chain reaction is more sensitive than microscopy for detecting low-grade infection, it detects only those individuals with active infection, whereas serology can identify those with recent exposure who may no longer be actively infected. Sero-surveillance offers a simple and sensitive tool that could be combined with other surveillance measures and geospatial analysis to identify hotspots and hot-pops for targeting with appropriate interventions.

Sero-surveillance could be used to verify that malaria has been eliminated since the absence of antibodies in the youngest age groups indicates that malaria transmission has been interrupted $[10,15,21]$. Post-elimination, there remains a need to screen mobile populations at risk of transmission [7]. Serology is unlikely to be useful for diagnosing actively infected individuals because antibodies take days to develop and persist after infection has resolved $[8,10]$, but serology might identify high-risk groups suitable for active case detection [18]. Serosurveillance might also identify populations at risk of outbreaks as immunity wanes in the face of declining malaria transmission, but this will require further research to identify robust correlates of anti-malarial immunity $[22,23]$.

Sero-surveillance is likely to be used mainly for monitoring the transmission of, and exposure to, P. falciparum and $P$. vivax and may prove helpful for identifying individuals with $P$. vivax hypnozoites (which are responsible for $P$. vivax relapses) [18], although a suitable serological test is required. Further research is needed to determine whether serology could be a useful tool for 
monitoring the exposure to $P$. ovale, $P$. malariae, and $P$. knowlesi or evaluating the burden and distribution of these species in populations [24].

\section{Development of serological tests for malaria surveillance}

A number of knowledge gaps need to be addressed in order to develop and optimize sero-surveillance tools for use in malaria control programs (Table 2). Ideal tests would provide information about long-term or recent exposure (or both) and be highly sensitive and speciesspecific. The intended application and target population need to be clearly defined as these will determine the technical performance required from tests, which in turn is achieved largely by appropriate selection of antigens with a strong knowledge of antibody responses to candidate antigens. Non-invasive testing would be preferable to optimize the acceptability of a sero-surveillance program, especially if children were to be the major target group and malaria were no longer viewed as a major health threat. Point-of-care testing would facilitate data collection and allow rapid feedback to communities to enhance commitment to control programs. Tests should be standardized so that data could be compared between populations and geographical regions. Standardization should extend to recombinant proteins used (including expression systems), serum dilutions, Immunoglobulin G (IgG) subclass(es) detected, and the definition and calculation of seropositivity [10]. Any test would need to be carefully validated against data from parasitemia and vector surveillance and data on seasonality, spatial distribution of malaria, and other epidemiologic data. Figure 1 provides a general model for the development of sero-surveillance tests.

\section{Antigen selection}

Of more than 5,000 proteins expressed by the Plasmodium species, few have been examined in any detail [25],

Table 2. Research priorities for developing malaria sero-surveillance tests

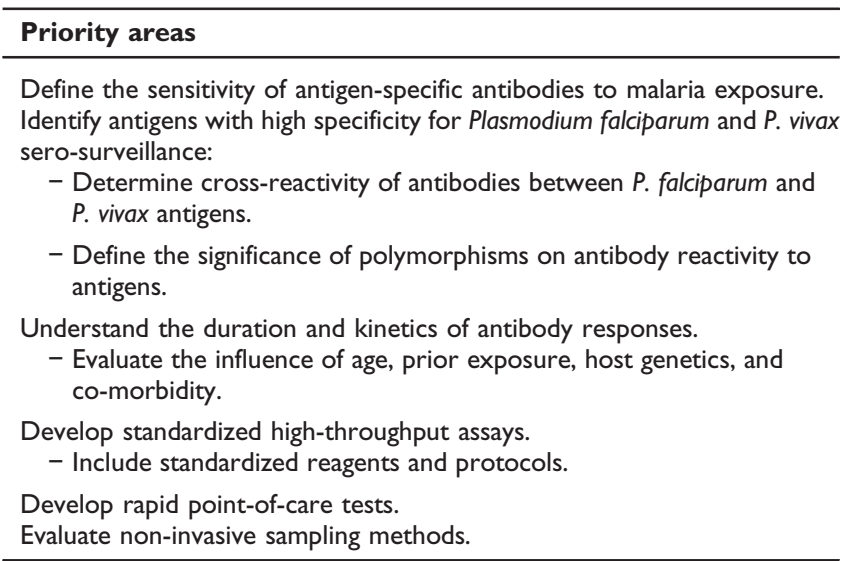

Figure I. A model for the development of malaria sero-surveillance assays and tests

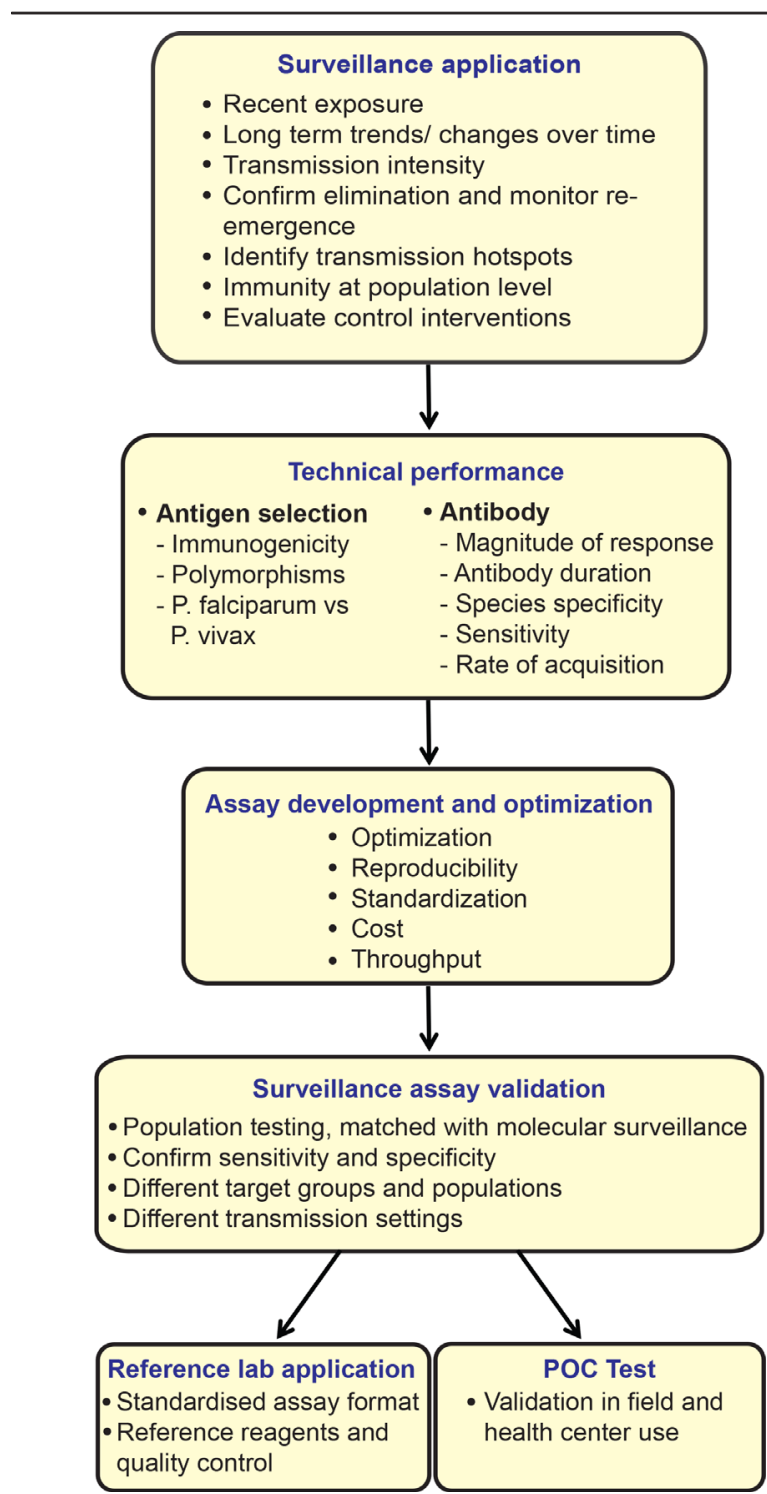

There are various possible applications and target populations for serosurveillance, and these will determine the technical performance required from antibody assays and tests to best meet the surveillance needs. The properties of the antigens and antibody responses are the key determinants of the performance and suitability of assays and tests, and different technical performance characteristics will be required for different applications and target populations. After developing and validating appropriate assays, considering specificity and sensitivity, assays will require validation in the appropriate target populations (for example, children, adults, pregnant women, and migrant workers) to establish or confirm their utility and in different populations and settings to ensure the generalizability of results. Subsequently, there are two primary applications of sero-surveillance assays: (i) as a serological assay to be performed in reference laboratories using standardized protocols with reference reagents and (ii) as a simple point-of-care (POC) test that can be used in community-based and health facility-based surveillance. 
and very few have been investigated as potential antigens for sero-surveillance. A comprehensive evaluation of candidate antigens is required to identify those antibody responses that are most sensitive for detecting changes in transmission. Studies employing protein microarrays $[26,27]$ or expanded repertoires of purified antigens [28] are beginning to address this knowledge gap. There is increasing recognition that antibody responses to single antigens have limited value as correlates of immunity or biomarkers of exposure $[26,28,29]$, and it is likely that multiple antigens will need to be included in serologic assays.

Antigen selection for sero-surveillance assays will be influenced by properties of the antigen, including immunogenicity, antibody longevity, polymorphism, and cross-reactivity between the Plasmodium species (Table 3). Antibodies to different antigens are acquired at different rates relative to exposure [26,28] (McCallum et al. unpublished data); therefore, antigens will need to be selected according to the application and setting. Highly immunogenic antigens, to which antibodies are acquired early in life or after limited exposure (for example, apical membrane antigen 1 [AMA1]), will be required for monitoring changes in transmission in low-endemicity settings. In moderate-to-high endemicity settings, other antigen-specific responses might better reflect recent changes in transmission (for example, erythrocyte-binding antigen [EBA], regions III-V; McCallum et al. unpublished data). Antigens with stable antibody responses will be

Table 3. Examples of potential antigens for use in sero-surveillance

\begin{tabular}{|c|c|c|c|c|}
\hline \multicolumn{5}{|c|}{ Antigens present in Plasmodium falciparum and $P$. vivax ${ }^{a}$} \\
\hline & AMAI & CSP & $\mathrm{MSPI}_{19}$ & MSP3 \\
\hline $\begin{array}{l}\text { Identity between } P f \text { and } P v \\
\text { sequences }\end{array}$ & $51 \%$ (Ecto-domain) & $25 \%$ & $45 \%$ & 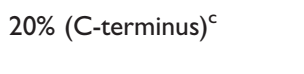 \\
\hline Polymorphisms & $\begin{array}{l}>10 \% \text { of ecto-domain amino } \\
\text { acids in PfAMAI and PvAMAI } \\
\text { are polymorphic. Antibodies } \\
\text { also target cross-reactive } \\
\text { epitopes }\end{array}$ & $\begin{array}{l}\text { Substantial polymorphism. } \\
\text { Relatively conserved } \mathrm{N} \text { and } \\
\text { C-terminal domains flank the } \\
\text { highly polymorphic central } \\
\text { repeat regions. }\end{array}$ & $\begin{array}{l}\text { Limited polymorphism. } \\
\text { Pf-MSPI }_{19} \text { has } 4 \\
\text { polymorphic residues }\end{array}$ & $\begin{array}{l}\text { Substantial polymorphism: } \\
\text { PfMSP3 has central } \\
\text { polymorphic domain. } \\
\text { PvMSP3 } \alpha \text { has length and } \\
\text { sequence polymorphism. }\end{array}$ \\
\hline $\begin{array}{l}\text { Antibody cross-reactivity } \\
\text { between species }\end{array}$ & $\begin{array}{l}\text { Some cross-reactivity detected } \\
\text { with antibodies generated in } \\
\text { animals (unpublished data) }\end{array}$ & Unknown & Unknown & Unknown \\
\hline \multirow[t]{3}{*}{ Comments } & $\begin{array}{l}\text { I. PfAMAI and PvAMAI are } \\
\text { vaccine candidates }\end{array}$ & \multirow{2}{*}{$\begin{array}{l}\text { I. Leading vaccine candidate, } \\
\text { which may preclude its } \\
\text { use in sero-surveillance in } \\
\text { the future }\end{array}$} & \multirow{3}{*}{$\begin{array}{l}\text { Potential in sero- } \\
\text { surveillance has already } \\
\text { been demonstrated }\end{array}$} & \multirow{2}{*}{$\begin{array}{l}\text { I. Shown to be } \\
\text { immunogenic in many } \\
\text { different populations } \\
\text { and settings }\end{array}$} \\
\hline & \multirow{2}{*}{$\begin{array}{l}\text { 2. Potential value in sero- } \\
\text { surveillance already } \\
\text { demonstrated }\end{array}$} & & & \\
\hline & & $\begin{array}{l}\text { 2. Potential in sero- } \\
\text { surveillance has been } \\
\text { demonstrated }\end{array}$ & & $\begin{array}{l}\text { 2. PfMSP3 is currently in } \\
\text { vaccine trials }\end{array}$ \\
\hline \multicolumn{5}{|c|}{ Antigens unique to $P$. falciparum } \\
\hline & EBAI75 & MSP2 & VAR2CSA & PfRH2 \\
\hline Polymorphisms & $\begin{array}{l}\text { Significant polymorphism in } \\
\text { region 2; limited polymorphism } \\
\text { in regions 3-5. }\end{array}$ & $\begin{array}{l}\text { Polymorphisms group into } \\
\text { two allelic families }\end{array}$ & $\begin{array}{l}\text { Moderate polymorphism, } \\
\text { but antibodies also } \\
\text { target cross-reactive } \\
\text { epitopes }\end{array}$ & $\begin{array}{l}\mathrm{N} \text {-terminal region is } \\
\text { polymorphic. Other } \\
\text { immunogenic regions are } \\
\text { conserved }\end{array}$ \\
\hline \multirow[t]{2}{*}{ Comments } & $\begin{array}{l}\text { I. Influence of polymorphisms } \\
\text { on antibody reactivity is unclear. }\end{array}$ & \multirow{2}{*}{$\begin{array}{l}\text { Significant potential in sero- } \\
\text { surveillance has been } \\
\text { demonstrated }\end{array}$} & \multirow{2}{*}{$\begin{array}{l}\text { Use would be restricted } \\
\text { to sero-surveillance of } \\
\text { malaria in pregnant } \\
\text { women. }\end{array}$} & \multirow{2}{*}{$\begin{array}{l}\text { Immunogenic, but more } \\
\text { data needed on responses } \\
\text { in young children, or those } \\
\text { with limited malaria } \\
\text { exposure }\end{array}$} \\
\hline & $\begin{array}{l}\text { 2. Demonstrated immunogenicity } \\
\text { in young children }\end{array}$ & & & \\
\hline \multicolumn{5}{|c|}{ Antigens unique to $P$. vivax } \\
\hline & DBP & RBP I & & \\
\hline $\begin{array}{l}\text { Polymorphisms } \\
\text { Comments }\end{array}$ & $\begin{array}{l}\text { Significant polymorphism } \\
\text { Immunogenicity demonstrated } \\
\text { in many different populations }\end{array}$ & $\begin{array}{l}\text { Significant polymorphism } \\
\text { Immunogenic, but studies } \\
\text { are limited }\end{array}$ & & \\
\hline
\end{tabular}

${ }^{a}$ Many immunogenic proteins that could be used in sero-surveillance are present in both species. ${ }^{b}$ Comparison of $P$. falciparum 3D7 isolate with $P$. vivax Sal I isolate. ${ }^{C} \mathrm{C}$-terminus has the most conservation in sequence between species. AMAI, apical membrane protein I; CSP, circumsporozoite protein; DBP, Duffy-binding protein; EBAI75, erythrocyte binding antigen 175; MSP, merozoite surface protein; PfRH2, P. falciparum reticulocyte-binding homologue; RBPI, reticulocyte-binding protein I. 
preferred for measuring cumulative exposure and assessing changes in transmission over extended periods of time, whereas those with shorter-lived responses will be more useful for identifying recent exposure. Further research is needed to clearly define the longevity of antibody responses to candidate antigens (discussed further below). Choice of antigen will also be affected by the target population and application. Highly immunogenic antigens would be preferable for a target population of young children (for example, to confirm elimination), whereas antigens with short-lived antibody responses would be needed in an assay to identify subpopulations of adults with recent occupational exposure.

In the context of elimination programs, sensitivity and specificity of surveillance assays are both important to ensure high-risk subpopulations and geographical hotspots are correctly identified [18]. Many malaria antigens that are targets of naturally acquired antibodies have significant polymorphism that could compromise the sensitivity of a sero-surveillance test. If necessary, strain specificity could be circumvented by including different allelic variants in the assay.

Potential cross-reactivity of antibodies to antigens from different malaria species [30-32] could affect test specificity in areas where multiple malaria species are present (particularly both $P$. falciparum and P. vivax). Ideally, antigens would be selected that either are species-specific or that show substantial sequence diversity between species and limited antibody cross-reactivity (Table 3). Many antigens are conserved across $P$. falciparum and P. vivax, including antigens that have been most studied in serosurveillance (circumsporozoite protein [CSP], merozoite surface protein [MSP1], and AMA1), and the level of crossreactivity of antibodies needs to be further defined. Assays should be validated in regions where the parasite species coexist [8]. Examples of potential species-specific antigens for $P$. vivax include Duffy-binding protein (DBP) and reticulocyte-binding proteins (RBPs) [33,34], and for $P$. falciparum, MSP2, EBA175, and P. falciparum reticulocyte binding-like homologue protein 2 (PfRh2) are speciesspecific and show good immunoreactivity [35-37]. Although P. falciparum EBA-175 (PfEBA175) and PvDBP proteins both contain structurally related Duffy-bindinglike domains, the sequence identity between these domains is very low. For regions with other malaria species, potential antibody cross-reactivity would need to be investigated when developing sero-surveillance tools.

Another important consideration is that antigens that are included in malaria vaccines would not be suitable candidates for sero-surveillance tests because of the difficulty in differentiating between vaccine-induced and naturally acquired antibodies. The RTS, $\mathrm{S}$ vaccine is the most advanced malaria vaccine, now in phase three clinical trials, and is based on P. falciparum CSP [38,39]; if the vaccine was to be licensed, CSP would not be an ideal candidate for sero-surveillance tests.

\section{Potential antigens for $\boldsymbol{P}$. falciparum sero-surveillance}

To date, antibody responses to the merozoite antigens MSP1-19 and AMA1 have been most studied as markers of exposure to P. falciparum. Seroconversion rates for PfMSP1-19 antibodies have been strongly correlated with other indicators of transmission intensity (EIR, parasite rate, malaria incidence, and altitude) $[7,11-13,17]$. PfAMA1 is highly immunogenic [7,40-42], which may limit its value in detecting changes in transmission at moderate-to-high endemicity $[7,11,14]$, but it could be more appropriate than PfMSP1-19 antibodies for serosurveillance in very-low-transmission settings and for monitoring post-elimination. However, PfAMA1 is also a leading malaria vaccine candidate [43]; successful development of PfAMA1 as a vaccine would preclude its use in sero-surveillance in the future, although it could be used for the surveillance of vaccine coverage. Sero-surveillance based on PfMSP1-19 and PfAMA1 seroconversion rates has facilitated the identification of transmission hotspots $[12,44]$ and changes in transmission intensity over time [11], with accuracy consistent with or superior to that of conventional measures. Comparable results from multiple settings would support the inclusion of these antigens in a sero-surveillance test. Orthologues for these antigens are present in $P$. vivax, and potential cross-reactivity of antibodies to different species needs to be defined.

Antibody responses to other $P$. falciparum antigens have also shown potential for sero-surveillance, including bloodstage proteins-Pf MSP2 [7], PfMSP1-42 (the C-terminal 42-kDa fragment of MSP1) [16], Pf glutamate-rich protein (GLURP) [45]-and sporozoite (CSP) and liver-stage proteins, such as liver-stage antigen-1 (LSA-1) and thrombospondin-related adhesive protein (TRAP) [46-49]. Another approach may be to measure antibodies to specific antigen epitopes or alleles, which can be performed efficiently by using competition ELISAs [50].

Antibody responses to $P$. falciparum sexual-stage antigens appear considerably less prevalent than responses to asexual blood stage antigens, do not show a consistent relationship with transmission intensity or season, and appear to be very short-lived in the absence of circulating gametocytes [51-54], suggesting that they may be less suitable as markers of exposure in sero-surveillance.

An interesting possibility may be the use of the pregnancyassociated $P$. falciparum erythrocyte membrane protein 1 
(PfEMP1) variant VAR2CSA (variant surface antigen 2-CSA) [55] in sentinel populations of pregnant women; in studies in a low-transmission setting, antibodies to VAR2CSA by ELISA were strongly associated with $P$. falciparum infection during pregnancy [56].

Studies using protein microarrays to profile antibody responses have identified some promising candidate antigens that need further investigation as potential biomarkers [26,27,57]. Recent studies identified several promising antigen-specific responses that discriminate between regions with high and low $P$. falciparum transmission, including antigens MSP4, MSP5, DBL-MSP, and EXP1 (PF3D7_1121600) [57]. MSP4, MSP5, and EXP1 have orthologues in P. vivax (identity 30\%, 23\%, and 42\%, respectively; $P$. falciparum exp1 gene was compared with gene ID PVX_091700; Broad Institute, Cambridge, MA, USA). Orthologues of some P. falciparum antigens could be developed for $P$. vivax sero-surveillance but need to be carefully evaluated for possible cross-species reactivity of antibodies. Microarrays typically use proteins produced in a high-throughput manner and may not be optimally folded or represent the optimal constructs for antibody detection. Therefore, a lack of reactivity in microarrays should not be used to exclude specific antigens as promising candidates.

\section{Potential antigens for $P$. vivax sero-surveillance}

Far less information is available about $P$. vivax antigens for use in sero-surveillance. The best studied antigens are $P v \mathrm{CSP}, P v \mathrm{AMA} 1$, and PvMSP1-19 [15,44,45,58]; as these antigens have orthologues in $P$. falciparum, the extent of antibody cross-reactivity needs to be determined. Seroprevalence of $P v \mathrm{CSP}$ has been associated with other measures of transmission intensity [58-60], and seroreactivity to PvMSP1-19, PvAMA1, or PvCSP has been used as a marker of $P$. vivax transmission in regions where parasite prevalence was low $[44,61,62]$. Further research is required to investigate the potential of these antigens and expand the repertoire of $P$. vivax antigens as candidates for sero-surveillance as evidence supporting the use of antigens in sero-surveillance or as biomarkers of exposure is currently very limited. Antigens specific to $P$. vivax, such as DBP and RBP, may be alternatives. $P$. vivax poses additional challenges for surveillance. At present, there is no method for diagnosing asymptomatic hypnozoite carriers, and new infections cannot be distinguished from relapses [63]. It remains to be determined whether it is feasible to use antibodies to predict hypnozoite carriage and to identify suitable antigens for such an assay $[18,64]$.

Anti-salivary antibodies as biomarkers of exposure

Measuring the exposure to anopheline mosquitoes by human landing catches is insensitive at low transmission levels and cannot give an indication of individual exposure, and for ethical reasons is unable to be performed in children. A measurement of human antibodies to vector antigens is an alternative. IgG prevalence and levels to the Anopheles gambiae salivary gland protein 6 (gSG6) vary between regions with different transmission and show seasonal variation [65]. IgG levels also correlate well with mosquito exposure measured directly [66]. Measurement of anti-salivary antibodies could provide a method for evaluating vector control interventions that could be performed in parallel with other serological measures of exposure, but further research is needed to assess its utility. Assessment of anti-salivary antibodies may help distinguish new $P$. vivax infections from relapses [63].

\section{Biomarkers of immunity}

Sero-surveillance has the potential to provide information about population immunity as well as exposure [28]; as transmission declines and immunity wanes, communities or subgroups that might be vulnerable to outbreaks of disease could be identified to receive additional protective interventions. Antigens to be used as biomarkers of immunity will probably differ from those used as biomarkers of exposure. To date, clear correlates of anti-malarial immunity are still lacking [23], probably because research on anti-malarial immunity has focused on immune responses to a limited number of malaria antigens and most studies have measured antibody levels but not functional responses [22,23,35]. Recently, studies of expanded repertoires of new or littlestudied antigens have identified antigen-specific antibody responses associated with protection $[26,28]$. Data are emerging that antibodies to recombinant merozoite antigens are valuable biomarkers of immunity $[28,35]$. There has also been increased effort in recent years to delineate functional mechanisms of immunity and relate these to protection [67-73]; growth-inhibitory antibodies have not been consistently predictive of protective immunity, whereas emerging data suggest that opsonic phagocytosis of merozoites may be a strong correlate of immunity $[69,71,74]$. However, additional prospective studies linking functional antibody responses to clinical outcomes are required.

\section{Serology platforms, point-of-care tests and non-invasive testing}

A number of platforms or methodologies are currently being explored for application in sero-surveillance. These include: (a) ELISA, which is the most widely established and used method; (b) suspension bead arrays (antigens are coated onto fluorescent beads), which allow simultaneous testing of multiple antigens, and (c) protein microarrays. The advantages and disadvantages of these approaches are summarized in Table 4. Each of these 
Table 4. Advantages and disadvantages of different sero-surveillance platforms

\begin{tabular}{|c|c|c|c|}
\hline Platform & Advantages & Disadvantages & Comments \\
\hline ELISA & $\begin{array}{l}\text { - Established and widely used technology } \\
\text { - Efficient, high-throughput } \\
\text { - Relatively low cost } \\
\text { - Limited technical expertise required } \\
\text { - Semi-automated technology available } \\
\text { - Competition ELISAs possible to } \\
\text { measure antibodies to epitopes or } \\
\text { alleles }\end{array}$ & $\begin{array}{l}\text { - Typically tests only a single antigen at a } \\
\text { time } \\
\text { - Requires laboratory facilities }\end{array}$ & $\begin{array}{l}\text { - Suitable for reference lab application } \\
\text { - May be adaptable for use by survey } \\
\text { teams with portable equipment }\end{array}$ \\
\hline Bead arrays & $\begin{array}{l}\text { - Efficient, high-throughput } \\
\text { - Able to test multiple antigen-specific } \\
\text { responses simultaneously }\end{array}$ & $\begin{array}{l}\text { - Relatively costly } \\
\text { - Requires a high level of technical expertise } \\
\text { - Requires laboratory facilities } \\
\text { - Extensive optimization of antigen-coated } \\
\text { beads required }\end{array}$ & - Suitable for reference lab application \\
\hline Protein microarrays & $\begin{array}{l}\text { Evaluate antibodies to an extensive } \\
\text { array of antigens }\end{array}$ & $\begin{array}{l}\text { - Costly } \\
\text { - Requires a very high level of technical } \\
\text { expertise } \\
\text { - Requires laboratory facilities } \\
\text { - Requires production of a large number of } \\
\text { antigens }\end{array}$ & $\begin{array}{l}\text { - Currently being used for antigen } \\
\text { discovery } \\
\text { - May be suitable for reference lab } \\
\text { application }\end{array}$ \\
\hline Point-of-care test & $\begin{array}{l}\text { - Allows testing in communities or at } \\
\text { health facilities } \\
\text { - Result within minutes provides } \\
\text { real-time data to staff and participants } \\
\text { - Low cost } \\
\text { - No technical expertise or lab facilities } \\
\text { required }\end{array}$ & $\begin{array}{l}\text { - Limited to testing two or three antigens } \\
\text { - Semi-quantitative only } \\
\text { - Lower sensitivity than other methods }\end{array}$ & $\begin{array}{l}\text { - Suitable for community-based } \\
\text { screening and reference lab } \\
\text { application }\end{array}$ \\
\hline
\end{tabular}

ELISA, enzyme-linked immunosorbent assay.

platforms needs to be carefully evaluated in sero-surveillance applications, and further studies comparing their technical performance are needed. A further approach is the use of point-of-care tests, which provide rapid results at the site of clinical services or screening so that timely treatment decisions can be made [75], and they are often in the form of simple lateral flow immunochromatographic devices. They have proven to be valuable for the diagnosis and management of infectious diseases, such as HIV and malaria, and show potential for infectious disease surveillance [76]. Point-of-care testing for antimalarial antibodies could reduce costs, simplify testing, avoid cold chain requirements for collected samples, reduce time for results to reach central agencies, and provide immediate feedback to individuals and communities about ongoing exposure, which could encourage commitment to control interventions. They are less sensitive than ELISA or suspension bead arrays but would be expected to have sufficient sensitivity for sero-surveillance applications.

Non-invasive sampling methods would improve acceptability in communities, simplify collection (reducing required expertise and associated costs), and minimize the risks of blood-borne infection [63]. Saliva and urine both contain low concentrations of antibodies to malaria [77-79], and a good correlation has been observed between oral fluid or saliva and plasma for antibodies against whole $P$. falciparum asexual blood stage antigen [79] or PfAMA1 and PfMSP1-19 [78]; however, the sensitivity of assays based on these samples is lower than for blood samples. Further research is required to optimize and standardize methodology, test under a range of different conditions, and trial antibodies to additional antigens, including P. vivax antigens.

\section{Estimating malaria transmission and exposure by using antibody data}

Factors affecting the acquisition and maintenance of antimalarial antibodies and how these influence the relationship between antibody measurements and transmission intensity are not well understood. A greater understanding of these factors would allow the development of sero-surveillance tools and analysis approaches and models to derive estimates of malaria transmission in populations, quantify the impact of malaria control interventions, identify hotspots of malaria transmission, and confirm malaria elimination in a range of populations and transmission settings. 


\section{The influence of age}

Young children are an attractive target group for serosurveillance because detection of antibodies indicates recent presence of malaria in a population [10]. However, age-related effects on antibody acquisition and maintenance could mean that focusing sero-surveillance on young children leads to the transmission being underestimated. In young children, seroconversion rates and antibody magnitude are lower, isotype switching is reduced, and antibody levels may wane more quickly [80]. Anti-merozoite antibody responses of very short duration (days to weeks) have been reported in some studies of children under 3 years [81,82], and anti-malarial antibody longevity increases with age $[26,82,83]$. Additionally, the presence of maternally derived antibodies in infants up to 12 months of age means that an antibody may not be an accurate measure of exposure in this age group [8]. To derive valid estimates of transmission intensity based on serological data collected from children, research is required to identify malarial antigens that are immunogenic in younger age groups and to define the effects of age, exposure, and transmission intensity on rates of seroconversion and seroreversion.

\section{Exposure history}

Differences in the extent, duration, and timing of malaria exposure might differentially affect the acquisition and maintenance of anti-malarial antibodies and so impact on the estimates of transmission intensity derived from serological data. There is some evidence that the persistence of anti-malarial antibody increases with the degree of past exposure [26,84], which could be explained by the accumulation of specific long-lived plasma cells in the bone marrow $[83,85]$. Conversely, other studies suggest that the development and survival of long-lived plasma cells and memory B cells in malaria may be dysregulated under conditions of repeated malaria infection with an impact on antibody maintenance [83,86-89]. Despite this, model fitting of MSP1-19 antibody data from different regions in Tanzania has suggested that the seroreversion rate is independent of transmission intensity [8]. Further studies delineating the relationship between seroprevalence and transmission intensity need to be conducted among populations with different levels of exposure.

\section{Genetics and comorbidity}

There is some evidence that host genetics affect antibody responses to some malarial antigens $[8,48,90-96]$, and this will need to be considered when using sero-surveillance among genetically diverse populations. Co-morbidity, including HIV infection [97,98] and malnutrition $[99,100]$, might reduce seroconversion rates. Given that areas with the greatest burden of malaria often also have a high prevalence of HIV and malnutrition, further research on these interactions is needed.

\section{Antibody longevity}

Available data on the longevity of anti-malarial antibody responses are limited and vary significantly between studies. Estimated half-lives for the same antibody response may vary from days to months to years in different studies $[56,81,82]$. Differences may be explained by major differences in the age and background immunity of studied populations and by differing levels of transmission. An additional explanation is that measurements have been made at different phases of the antibody response. Those studies reporting antibody response half-lives of weeks to months have generally used data from acutely infected individuals following drug treatment [81,82]. Studies that have not specifically focused on individuals with acute infection usually report longer half-lives $[7,56,101]$. It has been estimated that human antibody responses do not reach steady state until 2 to 3 years after infection or vaccination [102]. Data on antibody half-life determined by testing exposed individuals who have not had recent infection (for example, migrants from endemic areas and travelers) may more accurately reflect antibody longevity because antibodies are measured in the stable decay phase.

Published studies [56,82] and our own unpublished data indicate that the longevity of antibody responses varies for different malarial antigens independently of the response magnitude. It has been suggested that the magnitude of B cell signaling determines plasma cell longevity [102], so intrinsic properties of the antigen, such as accessibility, size, abundance, epitope density, and how readily it may be processed and presented to T cells, might all contribute $[27,103,104]$. The dominant IgG subclass produced against different antigens or domains varies [36,105], and since each subclass is cleared at a different rate [106], this might also affect the longevity of different antibody responses. Additionally, studies demonstrate substantial variation in antibody kinetics among individuals and fluctuation in levels over time $[56,107]$. Although serosurveillance is valuable at the population level, this wide variability between individuals suggests that serology may not be valuable for the diagnosis of malaria exposure among individuals. Antibody longevity will influence which responses are appropriate for different sero-surveillance applications; therefore, it is crucial that antibody kinetics is clearly defined.

\section{Sero-surveillance program development}

Further research is required to identify the best target populations for sero-surveillance programs. Cross-sectional 
household-based surveys provide accurate data but are time-consuming, operationally demanding, and costly, and once transmission becomes low, the sample sizes required make them unfeasible for the purposes of routine surveillance $[11,63]$. Children attending routine immunization services, school children, attendees at health services, and pregnant women attending antenatal services are accessible for surveillance provided that they can be shown to be representative of the wider population and sensitive to changes in transmission; selective testing of these potential sentinel surveillance populations would need to be accepted by their communities $[11,63]$. The possibility of unequal exposure within different subgroups of a population (for example, age, gender, occupation, and ethnicity) needs to be considered when selecting the sample population. Rapid declines from high transmission levels will be most readily detected in younger children, since older children and adults are likely to have higher and more stable antibody responses [7]. Children born after transmission has been successfully interrupted will be seronegative and may make an ideal sample population for confirming elimination [10]; however, infants may have detectable maternally derived antibodies up to the age of 12 months [8]. It is likely that the most appropriate target population will vary for different settings and communities.

Research is required to establish optimum sample size, timing (in relation to seasons), and frequency of sampling for sero-surveillance, and all of these factors will need to be tailored to the particular populations and settings in which serological surveys are to be conducted. Large sample sizes, including a broad range of ages, will be required to generate the best estimates of transmission intensity in pre-elimination settings [8]. Consent and ethical issues for population screenings must be considered. Appropriate infrastructure in-country is also required to process serology tests and data and to feedback findings into regional and national malaria control initiatives. Rigorous assessment of the feasibility, cost-effectiveness, and acceptability of sero-surveillance programs needs to be conducted in each area where such programs are planned, prior to implementation [108], and strategies must be developed for ongoing monitoring and evaluation of program performance. Finally, sero-surveillance strategies would need to be integrated into a wider surveillance program that includes sensitive assays for detection of asymptomatic parasitemia, clinical case reporting, antimalarial drug use and resistance, and vector surveillance.

\section{Conclusions}

There is significant potential for the application of serosurveillance tools and strategies to accelerate malaria control and elimination. Here, we have identified a number of knowledge gaps that need to be addressed in order to develop and optimize sero-surveillance tools and their application in different settings and to maximize their value in malaria control. The development of serosurveillance tests that are accurate and reliable, that provide information about recent and long-term exposure, and that can be used as a point-of-care test or in resource-limited settings would be highly valuable. Antibody responses to relatively few antigens have been studied in this context, particularly for $P$. vivax, and a broader range of antigens needs to be examined to identify those responses that best detect changes in transmission at different levels of endemicity. It is still not clear how antigenic diversity and inter-species cross-reactivity might impact on the sensitivity and specificity of serological assays. Ultimately, a sero-surveillance test will probably include multiple antigens or variants to maximize sensitivity and will probably need to be tailored to different transmission conditions. Fundamental knowledge of factors affecting antibody acquisition and maintenance are needed so that valid estimates of transmission intensity can be derived from serological data in a variety of populations and settings. Finally, programmatic research is required to validate selected target populations and assess feasibility, acceptability, and cost-effectiveness and to develop approaches to integrate sero-surveillance into malaria control and elimination programs and link with other surveillance strategies.

\section{Abbreviations}

AMA1, apical membrane antigen A; CSP, circumsporozoite protein; DBP, Duffy-binding protein; EBA, erythrocyte-binding antigen; EIR, entomological inoculation rate; ELISA, enzyme-linked immunosorbent assay; IgG, immunoglobulin G; MSP, merozoite surface protein; RBP, reticulocyte-binding protein; VAR2CSA, variant surface antigen 2-CSA.

\section{Disclosures}

The funding agencies listed in the acknowledgements had no role in the preparation of this article or in the decision to publish.

\section{Acknowledgments}

Funding was provided by the National Health and Medical Research Council of Australia (NHMRC) (Senior Research Fellowship and Program Grant to James G. Beeson and Early Career Fellowship to Jack S. Richards) and the Australia Research Council (Future Fellowship to Freya J.I. Fowkes). The Burnet Institute was supported by funds from the NHMRC Independent Research Institutes Infrastructure Support Scheme and by a Victorian State Government Operational Infrastructure Support grant. 


\section{References}

I. Greenwood BM: Control to elimination: implications for malaria research. Trends Parasitol 2008, 24:449-54.

2. World Health Organization: World Malaria Report 2012. Geneva; 2012.

3. Snow RW, Marsh K: Malaria in Africa: progress and prospects in the decade since the Abuja Declaration. Lancet 2010, 376:137-9.

4. O'Meara WP, Mangeni JN, Steketee R, Greenwood B: Changes in the burden of malaria in sub-Saharan Africa. Lancet Infect Dis 2010, 10:545-55

5. Ceesay SJ, Casals-Pascual C, Erskine J, Anya SE, Duah NO, Fulford Anthony JC, Sesay Sanie SS, Abubakar I, Dunyo S, Sey O, Palmer A, Fofana M, Corrah T, Bojang KA, Whittle HC, Greenwood BM, Conway DJ: Changes in malaria indices between 1999 and 2007 in The Gambia: a retrospective analysis. Lancet 2008, 372:1545-54.

6. Okiro EA, Alegana VA, Noor AM, Snow RW: Changing malaria intervention coverage, transmission and hospitalization in Kenya. Malar J 2010, 9:285.

7. Drakeley CJ, Corran PH, Coleman PG, Tongren JE, McDonald SLR, Carneiro I, Malima R, Lusingu J, Manjurano A, Nkya WMM, Lemnge MM, Cox J, Reyburn H, Riley EM: Estimating medium- and long-term trends in malaria transmission by using serological markers of malaria exposure. Proc Natl Acad Sci USA 2005, 102:5 I08-13.

\section{FlOOOPrime}

\section{RECOMMENDED}

8. Corran P, Coleman P, Riley E, Drakeley C: Serology: a robust indicator of malaria transmission intensity? Trends Parasitol 2007, 23:575-82

9. Okell LC, Bousema T, Griffin JT, Ouédraogo AL, Ghani AC, Drakeley C]: Factors determining the occurrence of submicroscopic malaria infections and their relevance for control. Nat Commun 2012, 3:1237.

10. Drakeley C, Cook J: Chapter 5. Potential contribution of seroepidemiological analysis for monitoring malaria control and elimination: historical and current perspectives. Adv Parasitol 2009, 69:299-352.

I I. Stewart L, Gosling R, Griffin J, Gesase S, Campo J, Hashim R, Masika P, Mosha J, Bousema T, Shekalaghe S, CookJ, Corran P, Ghani A, Riley EM, Drakeley C: Rapid assessment of malaria transmission using age-specific sero-conversion rates. PLOS ONE 2009, 4:e6083.

\section{FlOOPrime}

\section{RECOMMENDED}

12. Bousema T, Drakeley C, Gesase S, Hashim R, Magesa S, Mosha F, Otieno S, Carneiro I, Cox J, Msuya E, Kleinschmidt I, Maxwell C, Greenwood B, Riley E, Sauerwein R, Chandramohan D, Gosling R: Identification of hot spots of malaria transmission for targeted malaria control. J Infect Dis 2010, 20I:I764-74.

13. Badu K, Afrane YA, Larbi J, Stewart VA, Waitumbi J, Angov E, Ong'echa JM, Perkins DJ, Zhou G, Githeko A, Yan G: Marked variation in MSP-II9 antibody responses to malaria in western Kenyan highlands. BMC Infect Dis 2012, I 2:50.

14. Cook J, Kleinschmidt I, Schwabe C, Nseng G, Bousema T, Corran PH, Riley EM, Drakeley CJ: Serological markers suggest heterogeneity of effectiveness of malaria control interventions on Bioko Island, equatorial Guinea. PLOS ONE 20I I, 6:e25। 37.

\section{FlOOOPrime}

\section{RECOMMENDED}

15. Cook J, Reid H, lavro J, Kuwahata M, Taleo G, Clements A, McCarthy J, Vallely A, Drakeley C: Using serological measures to monitor changes in malaria transmission in Vanuatu. Malar J 2010, 9:169.

16. Hsiang MS, Hwang J, Kunene S, Drakeley C, Kandula D, Novotny J, Parizo J, Jensen T, Tong M, Kemere J, Dlamini S, Moonen B, Angov E, Dutta S, Ockenhouse C, Dorsey G, Greenhouse B: Surveillance for malaria elimination in Swaziland: a national cross-sectional study using pooled PCR and serology. PLOS ONE 2012, 7:e29550.
17. Satoguina J, Walther B, Drakeley C, Nwakanma D, Oriero EC, Correa S, Corran P, Conway DJ, Walther M: Comparison of surveillance methods applied to a situation of low malaria prevalence at rural sites in The Gambia and Guinea Bissau. Malar J 2009, 8:274.

18. Sturrock Hugh JW, Hsiang MS, Cohen JM, Smith DL, Greenhouse B, Bousema T, Gosling RD: Targeting asymptomatic malaria infections: active surveillance in control and elimination. PLoS Med 2013, I0:el001467.

\section{FlOOOPrime
RECOMMENDED}

19. Cotter C, Sturrock Hugh JW, Hsiang MS, Liu J, Phillips AA, Hwang J, Gueye CS, Fullman N, Gosling RD, Feachem Richard GA: The changing epidemiology of malaria elimination: new strategies for new challenges. Lancet 2013, 382:900-I I.

\section{FlOOOPrime RECOMMENDED}

20. Okell LC, Ghani AC, Lyons E, Drakeley C]: Submicroscopic infection in Plasmodium falciparum-endemic populations: a systematic review and meta-analysis. J Infect Dis 2009, 200:I509-I7.

\section{FlOOOPrime
RECOMMENDED}

21. Erhart A, Thang ND, Bien TH, Tung NM, Hung NQ, Hung LX, Tuy TQ, Speybroeck N, Cong LD, Coosemans M, D'Alessandro U: Malaria epidemiology in a rural area of the Mekong Delta: a prospective community-based study. Trop Med Int Health 2004, 9: 108I-90.

22. Richards JS, Beeson JG: The future for blood-stage vaccines against malaria. Immunol Cell Biol 2009, 87:377-90.

23. Beeson JG, Fowkes FJl, Reiling L, Osier FH, Drew DR, Brown GV: Correlates of protection for Plasmodium falciparum malaria vaccine development: current knowledge and future research. In: Malaria Vaccine Development: Over 40 Years of Trials and Tribulations. edn. Edited by Giampietro C, Howard E: Future Medicine Ltd; 2014: 8I-104.

24. Doderer-Lang C, Atchade PS, Meckert L, Haar E, Perrotey S, Filisetti D, Aboubacar A, Pfaff AW, Brunet J, Chabi NW, Akpovi CD, Anani L, Bigot A, Sanni A, Candolfi E: The ears of the African elephant: unexpected high seroprevalence of Plasmodium ovale and Plasmodium malariae in healthy populations in Western Africa. Malar J 2014, I3:240.

25. Doolan DL: Plasmodium immunomics. Int J Parasitol 20 I I, 4 I:3-20.

26. Crompton PD, Kayala MA, Traore B, Kayentao K, Ongoiba A Weiss GE, Molina DM, Burk CR, Waisberg M, Jasinskas A, Tan X, Doumbo S, Doumtabe D, Kone Y, Narum DL, Liang X, Doumbo OK, Miller LH, Doolan DL, Baldi P, Felgner PL, Pierce SK: A prospective analysis of the $A b$ response to Plasmodium falciparum before and after a malaria season by protein microarray. Proc Natl Acad Sci USA 2010, 107:6958-63.

\section{FlOOOPrime
RECOMMENDED}

27. Doolan DL, Mu Y, Unal B, Sundaresh S, Hirst S, Valdez C, Randall A, Molina D, Liang X, Freilich DA, Oloo JA, Blair PL, Aguiar JC, Baldi P, Davies DH, Felgner PL: Profiling humoral immune responses to P. falciparum infection with protein microarrays. Proteomics 2008, 8:4680-94

\section{FlOOOPrime}

\section{RECOMMENDED}

28. Richards JS, Arumugam TU, Reiling L, Healer J, Hodder AN, Fowkes Freya Jl, Cross N, Langer C, Takeo S, Uboldi AD, Thompson JK, Gilson PR, Coppel RL, Siba PM, King CL, Torii M, Chitnis CE, Narum DL, Mueller I, Crabb BS, Cowman AF, Tsuboi T, Beeson JG: Identification and prioritization of merozoite antigens as targets of protective human immunity to Plasmodium falciparum malaria for vaccine and biomarker development. J Immunol 2013, 191:795-809.

29. Osier Faith HA, Fegan G, Polley SD, Murungi L, Verra F, Tetteh Kevin K A, Lowe B, Mwangi T, Bull PC, Thomas AW, Cavanagh DR, McBride IS, Lanar DE, Mackinnon MJ, Conway DJ, Marsh K: Breadth and magnitude of antibody responses to multiple Plasmodium 
falciparum merozoite antigens are associated with protection from clinical malaria. Infect Immun 2008, 76:2240-8.

\section{FIOOOPrime}

30. Igonet S, Vulliez-Le Normand B, Faure G, Riottot M, Kocken Clemens HM, Thomas AW, Bentley GA: Cross-reactivity studies of an anti-Plasmodium vivax apical membrane antigen I monoclonal antibody: binding and structural characterisation. $J \mathrm{Mol}$ Biol 2007, 366: I523-37.

31. Woodberry T, Minigo G, Piera KA, Hanley JC, de Silva, Harini D, Salwati E, Kenangalem E, Tjitra E, Coppel RL, Price RN, Anstey NM, Plebanski M: Antibodies to Plasmodium falciparum and Plasmodium vivax merozoite surface protein $\mathbf{5}$ in Indonesia: speciesspecific and cross-reactive responses. J Infect Dis 2008, I 98: I 34-42.

32. Cochrane AH, Nardin EH, Arruda M de, Maracic M, Clavijo P, Collins WE, Nussenzweig RS: Widespread reactivity of human sera with a variant repeat of the circumsporozoite protein of Plasmodium vivax. Am J Trop Med Hyg 1990, 43:446-5 I.

33. Tran TM, Oliveira-Ferreira J, Moreno A, Santos F, Yazdani SS, Chitnis CE, Altman JD, Meyer EV, Barnwell JW, Galinski MR: Comparison of IgG reactivities to Plasmodium vivax merozoite invasion antigens in a Brazilian Amazon population. Am J Trop Med Hyg 2005, 73:244-55.

34. Cole-Tobian JL, Michon P, Biasor M, Richards JS, Beeson JG, Mueller I, King CL: Strain-specific duffy binding protein antibodies correlate with protection against infection with homologous compared to heterologous plasmodium vivax strains in Papua New Guinean children. Infect Immun 2009, 77:4009-I7.

35. Fowkes Freya JI, Richards JS, Simpson JA, Beeson JG: The relationship between anti-merozoite antibodies and incidence of Plasmodium falciparum malaria: $A$ systematic review and meta-analysis. PLoS Med 2010, 7:el000218.

36. Richards JS, Stanisic DI, Fowkes Freya JI, Tavul L, Dabod E, Thompson JK, Kumar S, Chitnis CE, Narum DL, Michon P, Siba PM, Cowman AF, Mueller I, Beeson JG: Association between naturally acquired antibodies to erythrocyte-binding antigens of Plasmodium falciparum and protection from malaria and high-density parasitemia. Clin Infect Dis 2010, 51 :e50-60.

37. Reiling L, Richards JS, Fowkes Freya JI, Barry AE, Triglia T, Chokejindachai W, Michon P, Tavul L, Siba PM, Cowman AF, Mueller I, Beeson JG: Evidence that the erythrocyte invasion ligand PfRh2 is a target of protective immunity against Plasmodium falciparum malaria. J Immunol 2010, 185:6157-67.

38. RTSS Clinical Trials Partnership, Agnandji ST, Lell B, Fernandes JF, Abossolo BP, Methogo Barbara Gaelle Nfono Ondo, Kabwende AL, Adegnika AA, Mordmüller B, Issifou S, Kremsner PG, Sacarlal J, Aide P, Lanaspa M, Aponte J, Machevo S, Acacio S, Bulo H, Sigauque B, Macete E, Alonso P, Abdulla S, Salim N, Minja R, Mpina M, Ahmed S, Ali AM, Mtoro AT, Hamad AS, Mutani P, Tanner M, et al.: A phase 3 trial of RTS,S/ASOI malaria vaccine in African infants. $N$ Engl J Med 20I2, 367:2284-95.

\section{FlOOOPrime
RECOMMENDED}

39. Fowkes Freya JI, Simpson JA, Beeson JG: Implications of the licensure of a partially efficacious malaria vaccine on evaluating second-generation vaccines. BMC Med 2013, I I:232.

40. Thomas AW, Trape JF, Rogier C, Goncalves A, Rosario VE, Narum DL: High prevalence of natural antibodies against Plasmodium falciparum 83-kilodalton apical membrane antigen (PF83/AMA-I) as detected by capture-enzyme-linked immunosorbent assay using full-length baculovirus recombinant PF83/AMA-I. Am J Trop Med Hyg 1994, 5 I:730-40.

4I. Polley SD, Mwangi T, Kocken Clemens HM, Thomas AW, Dutta S, Lanar DE, Remarque E, Ross A, Williams TN, Mwambingu G, Lowe B, Conway DJ, Marsh K: Human antibodies to recombinant protein constructs of Plasmodium falciparum Apical Membrane Antigen I (AMAI) and their associations with protection from malaria. Vaccine 2004, 23:718-28.

42. Chelimo K, Ofulla AV, Narum DL, Kazura JW, Lanar DE, John CC: Antibodies to Plasmodium falciparum antigens vary by age and antigen in children in a malaria-holoendemic area of Kenya. Pediatr Infect Dis J 2005, 24:680-4.

43. Thera MA, Doumbo OK, Coulibaly D, Laurens MB, Ouattara A, Kone AK, Guindo AB, Traore K, Traore I, Kouriba B, Diallo DA, Diarra I, Daou M, Dolo A, Tolo Y, Sissoko MS, Niangaly A, Sissoko M, Takala-Harrison S, Lyke KE, Wu Y, Blackwelder WC, Godeaux O, Vekemans J, Dubois M, Ballou WR, Cohen J, Thompson D, Dube T, Soisson L, et al:: A field trial to assess a blood-stage malaria vaccine. $N$ Engl J Med 201 I, 365:1004-I3.

\section{FlOOOPrime}

RECOMMENDED

44. Bousema T, Youssef RM, Cook J, Cox J, Alegana VA, Amran J, Noor AM, Snow RW, Drakeley C: Serologic markers for detecting malaria in areas of low endemicity, Somalia, 2008. Emerging Infect Dis 2010, 16:392-9.

45. Cook J, Speybroeck N, Sochanta T, Somony H, Sokny M, Claes F, Lemmens K, Theisen M, Soares IS, D'Alessandro U, Coosemans $M$, Erhart A: Sero-epidemiological evaluation of changes in Plasmodium falciparum and Plasmodium vivax transmission patterns over the rainy season in Cambodia. Malar J 20I 2, I I:86.

46. John CC, Zickafoose JS, Sumba PO, King CL, Kazura JW: Antibodies to the Plasmodium falciparum antigens circumsporozoite protein, thrombospondin-related adhesive protein, and liverstage antigen I vary by ages of subjects and by season in a highland area of Kenya. Infect Immun 2003, 71:4320-5.

\section{FlOOOPrime}

\section{RECOMMENDED}

47. Noland GS, Hendel-Paterson B, Min XM, Moormann AM, Vulule JM, Narum DL, Lanar DE, Kazura JW, John CC: Low prevalence of antibodies to preerythrocytic but not blood-stage Plasmodium falciparum antigens in an area of unstable malaria transmission compared to prevalence in an area of stable malaria transmission. Infect Immun 2008, 76:5721-8.

48. Webster HK, Gingrich JB, Wongsrichanalai C, Tulyayon S, Suvarnamani A, Sookto P, Permpanich B: Circumsporozoite antibody as a serologic marker of Plasmodium falciparum transmission. Am J Trop Med Hyg 1992, 47:489-97.

49. Campo JJ, Whitman TJ, Freilich D, Burgess TH, Martin GJ, Doolan DL: Toward a surrogate marker of malaria exposure: modeling longitudinal antibody measurements under outbreak conditions. PLOS ONE 201I, 6:e21826.

50. Mugyenyi CK, Elliott SR, McCallum FJ, Anders RF, Marsh K, Beeson JG: Antibodies to polymorphic invasion-inhibitory and non-Inhibitory epitopes of Plasmodium falciparum apical membrane antigen I in human malaria. PLOS ONE 20 I3, 8:e68304.

5I. Ouédraogo AL, Roeffen W, Luty Adrian JF, de Vlas, Sake J, Nebie I, Ilboudo-Sanogo E, Cuzin-Ouattara N, Teleen K, Tiono AB, Sirima SB, Verhave J, Bousema T, Sauerwein R: Naturally acquired immune responses to Plasmodium falciparum sexual stage antigens Pfs 48/45 and Pfs230 in an area of seasonal transmission. Infect Immun 20II, 79:4957-64.

\section{FIOOOPrime
RECOMMENDED}

52. Bousema JT, Drakeley CJ, Sauerwein RW: Sexual-stage antibody responses to $\mathbf{P}$. falciparum in endemic populations. Curr Mol Med 2006, 6:223-9.

53. Bousema JT, Roeffen W, van der Kolk, Mike de Vlas, Sake J, van de Vegte-Bolmer Marga, Bangs MJ, Teelen K, Kurniawan L, Maguire JD, Baird JK, Sauerwein RW: Rapid onset of transmission-reducing antibodies in javanese migrants exposed to malaria in papua, indonesia. Am J Trop Med Hyg 2006, 74:425-3I.

54. Marrelli MT, Malafronte RS, Kloetzel JK: Seasonal variation of antiPlasmodium falciparum antibodies directed against a repetitive peptide of gametocyte antigen pfs 2400 in inhabitants in the State of Amapá, Brazil. Acta Trop 1997, 63:167-77.

55. Salanti A, Staalsoe T, Lavstsen T, Jensen Anja TR, Sowa MP Kordai, Arnot DE, Hviid L, Theander TG: Selective upregulation of a single distinctly structured var gene in chondroitin sulphate 
A-adhering Plasmodium falciparum involved in pregnancyassociated malaria. Mol Microbiol 2003, 49: I79-9l.

\section{FlOOOPrime}

56. Fowkes Freya Jl, McGready R, Cross NJ, Hommel M, Simpson JA, Elliott SR, Richards JS, Lackovic K, Viladpai-Nguen J, Narum D, Tsuboi T, Anders RF, Nosten F, Beeson JG: New insights into acquisition, boosting, and longevity of immunity to malaria in pregnant women. J Infect Dis 2012, 206:16I2-2I.

57. Baum E, Badu K, Molina DM, Liang X, Felgner PL, Yan G: Protein microarray analysis of antibody responses to Plasmodium falciparum in western Kenyan highland sites with differing transmission levels. PLOS ONE 2013, 8:e82246.

\section{FlOOOPrime}

58. Ramasamy R, Nagendran K, Ramasamy MS: Antibodies to epitopes on merozoite and sporozoite surface antigens as serologic markers of malaria transmission: studies at a site in the dry zone of Sri Lanka. Am J Trop Med Hyg 1994, 50:537-47.

\section{FlOOOPrime} RECOMMENDED

59. Lee KN, Suh IB, Chang EA, Kim SD, Cho NS, Park PW, An Seong Soo A, Park O, Lim C: Prevalence of antibodies to the circumsporozite protein of Plasmodium vivax in five different regions of Korea. Trop Med Int Health 2003, 8: I062-7.

\section{FlOOOPrime \\ RECOMMENDED}

60. Lim CS, Yoon JK, Chang EA, Suh IB, An Seong Soo A, Lee K, Chung JT, Tockgo YC: Seroprevalence to the circumsporozoite protein peptide antigen of Plasmodium vivax in Korean children. Microbiol Immunol 2005, 49:52I-7.

\section{FlOOOPrime}

\section{RECOMMENDED}

61. Mendis C, Del Giudice G, Gamage-Mendis AC, Tougne C, Pessi A, Weerasinghe S, Carter R, Mendis KN: Anti-circumsporozoite protein antibodies measure age related exposure to malaria in Kataragama, Sri Lanka. Parasite Immunol 1992, 14:75-86.

62. Culleton R, Ndounga M, Zeyrek FY, Coban C, Casimiro PN, Takeo S, Tsuboi T, Yadava A, Carter R, Tanabe K: Evidence for the transmission of Plasmodium vivax in the Republic of the Congo, West Central Africa. J Infect Dis 2009, 200:1465-9.

63. The malERA Consultative Group on Monitoring Evaluation and Surveillance: A research agenda for malaria eradication: monitoring, evaluation, and surveillance. PLoS Med 20I I, 8:e 1000400.

\section{FlOOOPrime} RECOMMENDED

64. The malERA Consultative Group on Diagnoses and Diagnostics: $A$ research agenda for malaria eradication: diagnoses and diagnostics. PLoS Med 20I I, 8:el000396.

\section{FlOOOPrime} RECOMMENDED

65. Badu K, Siangla J, Larbi J, Lawson BW, Afrane Y, Ong'echa J, Remoue F, Zhou G, Githeko AK, Yan G: Variation in exposure to Anopheles gambiae salivary gland peptide (gSG6-PI) across different malaria transmission settings in the western Kenya highlands. Malar J 2012, II:318

\section{FlOOOPrime}

66. Stone W, Bousema T, Jones S, Gesase S, Hashim R, Gosling R, Carneiro I, Chandramohan D, Theander T, Ronca R, Modiano D, Arcà B, Drakeley C: IgG responses to Anopheles gambiae salivary antigen gSG6 detect variation in exposure to malaria vectors and disease risk. PLOS ONE 2012, 7:e40I70.

\section{FlOOOPrime}

67. Crompton PD, Miura K, Traore B, Kayentao K, Ongoiba A, Weiss G, Doumbo S, Doumtabe D, Kone Y, Huang C, Doumbo OK, Miller LH,
Long CA, Pierce SK: In vitro growth-inhibitory activity and malaria risk in a cohort study in mali. Infect Immun 2010, 78:737-45

68. Wilson DW, Fowkes Freya II, Gilson PR, Elliott SR, Tavul L, Michon P, Dabod E, Siba PM, Mueller I, Crabb BS, Beeson JG: Quantifying the importance of MSPI-19 as a target of growth-inhibitory and protective antibodies against Plasmodium falciparum in humans. PLOS ONE 20II, 6:e27705

69. Joos C, Marrama L, Polson Hannah EJ, Corre S, Diatta A, Diouf B, Trape J, Tall A, Longacre S, Perraut R: Clinical protection from falciparum malaria correlates with neutrophil respiratory bursts induced by merozoites opsonized with human serum antibodies. PLoS ONE 2010, 5:e987I

\section{FlOOOPrime}

70. Reiling L, Richards JS, Fowkes Freya JI, Wilson DW Chokejindachai W, Barry AE, Tham W, Stubbs J, Langer C, Donelson J, Michon P, Tavul L, Crabb BS, Siba PM, Cowman AF, Mueller I, Beeson JG: The Plasmodium falciparum erythrocyte invasion ligand Pfrh4 as a target of functional and protective human antibodies against malaria. PLoS ONE 2012, 7:e45253.

7I. Osier FH, Feng G, Boyle MJ, Langer C, Zhou J, Richards JS, McCallum FJ, Reiling L, Jaworowski A, Anders RF, Marsh K, Beeson JG: Opsonic phagocytosis of Plasmodium falciparum merozoites: mechanism in human immunity and a correlate of protection against malaria. BMC Med 2014, 12:108.

72. Persson Kristina EM, Fowkes Freya Jl, McCallum FJ, Gicheru N, Reiling L, Richards JS, Wilson DW, Lopaticki S, Cowman AF, Marsh K, Beeson JG: Erythrocyte-binding antigens of Plasmodium falciparum are targets of human inhibitory antibodies and function to evade naturally acquired immunity. I Immunol 2013, | $91: 785-94$.

73. Tran TM, Ongoiba A, Coursen J, Crosnier C, Diouf A, Huang C, Li S, Doumbo S, Doumtabe D, Kone Y, Bathily A, Dia S, Niangaly M, Dara C, Sangala J, Miller LH, Doumbo OK, Kayentao K, Long CA, Miura K, Wright G], Traore B, Crompton PD: Naturally acquired antibodies specific for Plasmodium falciparum reticulocytebinding protein homologue 5 inhibit parasite growth and predict protection from malaria. J Infect Dis 2014, 209:789-98.

74. Hill DL, Eriksson EM, Li Wai Suen, Connie SN, Chiu CY, RygCornejo V, Robinson LI, Siba PM, Mueller I, Hansen DS, Schofield L. Opsonising antibodies to $\mathbf{P}$. falciparum merozoites associated with immunity to clinical malaria. PLOS ONE 2013, 8: e74627.

\section{FIOOOPrime}

\section{RECOMMENDED}

75. Pai NP, Vadnais C, Denkinger C, Engel N, Pai M: Point-of-care testing for infectious diseases: diversity, complexity, and barriers in low- and middle-income countries. PLoS Med 2012, 9:e1001306.

\section{FlOOOPrime}

76. Heymann DL, Brilliant L: Surveillance in eradication and elimination of infectious diseases: a progression through the years. Vaccine 20II, 29(Suppl 4):DI4I-4.

77. Rodriguez-del Valle M, Quakyi IA, Amuesi J, Quaye JT, Nkrumah FK, Taylor DW: Detection of antigens and antibodies in the urine of humans with Plasmodium falciparum malaria. J Clin Microbiol 1991, 29:1236-42.

78. Estévez PT, Satoguina J, Nwakanma DC, West S, Conway DJ, Drakeley C]: Human saliva as a source of anti-malarial antibodies to examine population exposure to Plasmodium falciparum. Malar J 20 I I, I 0: 104.

\section{FlOOOPrime}

79. Chidi AP, Chishimba S, Kobayashi T, Hamapumbu H, Mharakurwa S, Thuma PE, Moss W]: Validation of oral fluid samples to monitor 
serological changes to Plasmodium falciparum: an observational study in southern Zambia. Malar J 201 I, I 0:162.

\section{FIOOOPrime}

80. Siegrist $C$, Aspinall $R$ : B-cell responses to vaccination at the extremes of age. Nat Rev Immunol 2009, 9:185-94.

8I. Kinyanjui SM, Conway DJ, Lanar DE, Marsh K: IgG antibody responses to Plasmodium falciparum merozoite antigens in Kenyan children have a short half-life. Malar J 2007, 6:82.

\section{FlOOOPrime} RECOMMENDED

82. Akpogheneta OJ, Duah NO, Tetteh Kevin KA, Dunyo S, Lanar DE, Pinder M, Conway DJ: Duration of naturally acquired antibody responses to blood-stage Plasmodium falciparum is age dependent and antigen specific. Infect Immun 2008, 76: I748-55.

83. Portugal S, Pierce SK, Crompton PD: Young lives lost as B cells falter: what we are learning about antibody responses in malaria. J Immunol 2013, 190:3039-46.

84. Weiss GE, Traore B, Kayentao K, Ongoiba A, Doumbo S, Doumtabe D, Kone Y, Dia S, Guindo A, Traore A, Huang C, Miura K, Mircetic M, Li S, Baughman A, Narum DL, Miller LH, Doumbo OK, Pierce SK, Crompton PD: The Plasmodium falciparum-specific human memory $B$ cell compartment expands gradually with repeated malaria infections. PLoS Pathog 2010, 6:e 1000912.

\section{FlOOOPrime}

\section{RECOMMENDED}

85. Chu VT, Berek C: The establishment of the plasma cell survival niche in the bone marrow. Immunol Rev 2013, 25I:I77-88.

86. Weiss GE, Crompton PD, Li S, Walsh LA, Moir S, Traore B, Kayentao K, Ongoiba A, Doumbo OK, Pierce SK: Atypical memory $B$ cells are greatly expanded in individuals living in a malariaendemic area. J Immunol 2009, 183:2176-82

\section{FlOOOPrime \\ RECOMMENDED}

87. Illingworth J, Butler NS, Roetynck S, Mwacharo J, Pierce SK, Bejon P, Crompton PD, Marsh K, Ndungu FM: Chronic exposure to Plasmodium falciparum is associated with phenotypic evidence of B and T cell exhaustion. J Immunol 2013, 190:1038-47.

\section{FlOOOPrime}

\section{RECOMMENDED}

88. Scholzen A, Sauerwein RW: How malaria modulates memory: activation and dysregulation of $B$ cells in Plasmodium infection. Trends Parasitol 2013, 29:252-62.

89. Nduati E, Gwela A, Karanja H, Mugyenyi C, Langhorne J, Marsh K, Urban BC: The plasma concentration of the B cell activating factor is increased in children with acute malaria. J Infect Dis 201I, 204:962-70.

\section{FlOOOPrime \\ RECOMMENDED}

90. Modiano D, Petrarca V, Sirima BS, Nebié I, Diallo D, Esposito F, Coluzzi M: Different response to Plasmodium falciparum malaria in west African sympatric ethnic groups. Proc Natl Acad Sci USA 1996, 93:I3206-II.

91. Dolo A, Modiano D, Maiga B, Daou M, Dolo G, Guindo H, Ba M, Maiga H, Coulibaly D, Perlman H, Blomberg MT, Touré YT, Coluzzi $M$, Doumbo O: Difference in susceptibility to malaria between two sympatric ethnic groups in Mali. Am J Trop Med Hyg 2005, 72:243-8.

92. Bolad A, Farouk SE, Israelsson E, Dolo A, Doumbo OK, Nebié I, Maiga B, Kouriba B, Luoni G, Sirima BS, Modiano D, Berzins K, TroyeBlomberg $M$ : Distinct interethnic differences in immunoglobulin $\mathbf{G}$ class/subclass and immunoglobulin $M$ antibody responses to malaria antigens but not in immunoglobulin $\mathbf{G}$ responses to nonmalarial antigens in sympatric tribes living in West Africa. Scand J Immunol 2005, 61:380-6.
93. Portugal S, Doumtabe D, Traore B, Miller LH, Troye-Blomberg M, Doumbo OK, Dolo A, Pierce SK, Crompton PD: B cell analysis of ethnic groups in Mali with differential susceptibility to malaria. Malar J 2012, I I: I62.

94. Pratt-Riccio LR, Lima-Junior JC, Carvalho Leonardo JM, Theisen M, Espíndola-Mendes EC, Santos F, Oliveira-Ferreira J, Goldberg AC, Daniel-Ribeiro CT, Banic DM: Antibody response profiles induced by Plasmodium falciparum glutamate-rich protein in naturally exposed individuals from a Brazilian area endemic for malaria. Am J Trop Med Hyg 2005, 73:1096-103.

95. Rosenberg $R$, Wirtz RA: Intrinsic individual differences in circumsporozoite antibody response at a hyperendemic malaria focus. Trans $R$ Soc Trop Med Hyg 1990, 84:206-8.

96. Razakandrainibe $R$, Thonier V, Ratsimbasoa A, Rakotomalala E, Ravaoarisoa E, Raherinjafy R, Andrianantenaina H, Voahanginirina $O$, Rahasana TE, Carod JF, Domarle O, Menard D: Epidemiological situation of malaria in Madagascar: baseline data for monitoring the impact of malaria control programmes using serological markers. Acta Trop 2009, I I I:I60-7.

97. Mount AM, Mwapasa V, Elliott SR, Beeson JG, Tadesse E, Lema VM, Molyneux ME, Meshnick SR, Rogerson SJ: Impairment of humoral immunity to Plasmodium falciparum malaria in pregnancy by HIV infection. Lancet 2004, 363:1860-7.

98. Flateau C, Le Loup G, Pialoux G: Consequences of HIV infection on malaria and therapeutic implications: a systematic review. Lancet Infect Dis 20I I, I I:54I-56.

99. Fillol F, Sarr JB, Boulanger D, Cisse B, Sokhna C, Riveau G, Simondon KB, Remoué $F$ : Impact of child malnutrition on the specific anti-Plasmodium falciparum antibody response. Malar J 2009, 8:116.

100. Genton B, Al-Yaman F, Ginny M, Taraika J, Alpers MP: Relation of anthropometry to malaria morbidity and immunity in Papua New Guinean children. Am J Clin Nutr 1998, 68:734-4I.

I0I. Wipasa J, Suphavilai C, Okell LC, Cook J, Corran PH, Thaikla K, Liewsaree W, Riley EM, Hafalla Julius Clemence R: Long-lived antibody and $B$ Cell memory responses to the human malaria parasites, Plasmodium falciparum and Plasmodium vivax. PLoS Pathog 2010, 6:el000770.

102. Amanna IJ, Slifka MK: Mechanisms that determine plasma cell lifespan and the duration of humoral immunity. Immunol Rev 2010, 236: I25-38.

103. Hoffman SL, Rogers WO, Carucci DJ, Venter JC: From genomics to vaccines: malaria as a model system. Nat Med 1998, 4:|35|-3.

104. Langhorne J, Albano FR, Hensmann M, Sanni L, Cadman E, Voisine C, Sponaas A: Dendritic cells, pro-inflammatory responses, and antigen presentation in a rodent malaria infection. Immunol Rev 2004, 201:35-47.

105. Stanisic DI, Richards JS, McCallum FJ, Michon P, King CL, Schoepflin S, Gilson PR, Murphy VJ, Anders RF, Mueller I, Beeson JG: Immunoglobulin $\mathbf{G}$ subclass-specific responses against Plasmodium falciparum merozoite antigens are associated with control of parasitemia and protection from symptomatic illness. Infect Immun 2009, 77: I I 65-74.

106. Mankarious S, Lee M, Fischer S, Pyun KH, Ochs HD, Oxelius VA, Wedgwood RJ: The half-lives of IgG subclasses and specific antibodies in patients with primary immunodeficiency who are receiving intravenously administered immunoglobulin. J Lab Clin Med I 988, I I 2:634-40.

107. White MT, Griffin JT, Akpogheneta O, Conway DJ, Koram KA, Riley EM, Ghani AC: Dynamics of the Antibody Response to Plasmodium falciparum Infection in African Children. J Infect Dis 2014.

\section{FlOOOPrime}

\section{RECOMMENDED}

108. The malERA Consultative Group on Health Systems and Operational Research: A research agenda for malaria eradication: health systems and operational research. PLoS Med 20I I, 8:el000397. 